Southern Illinois University Edwardsville SPARK

SIUE Faculty Research, Scholarship, and Creative Activity

$1-27-2016$

\title{
Rapid Access to Conformationally-Constrained Oxatricycles via Ugi-Smiles Couplings
}

Bree Richey

Southern Illinois University Edwardsville

Katelynn M. Mason

Southern Illinois University Edwardsville

Michael S. Meyers

Southern Illinois University Edwardsville

Sarah Luesse

Southern Illinois University Edwardsville, sluesse@siue.edu

Follow this and additional works at: http://spark.siue.edu/siue_fac

Part of the Organic Chemistry Commons

\section{Recommended Citation}

Richey, Bree; Mason, Katelynn M.; Meyers, Michael S.; and Luesse, Sarah, "Rapid Access to Conformationally-Constrained Oxatricycles via Ugi-Smiles Couplings" (2016). SIUE Faculty Research, Scholarship, and Creative Activity. 47.

http://spark.siue.edu/siue_fac/47

This Article is brought to you for free and open access by SPARK. It has been accepted for inclusion in SIUE Faculty Research, Scholarship, and Creative Activity by an authorized administrator of SPARK. For more information, please contact gpark@siue.edu. 


\section{Cover Page Footnote}

This is the Accepted Manuscript version of an article published by Elsevier in Tetrahedron Letters, available online at http://dx.doi.org/10.1016/j.tetlet.2015.12.068.

(C) 2013. This manuscript version is made available under the CC-BY-NC-ND 4.0 license http://creativecommons.org/licenses/by-nc-nd/4.0/

http://dx.doi.org/10.1016/j.tetlet.2015.12.068 


\title{
Rapid access to conformationally-constrained oxatricycles via Ugi-Smiles couplings
}

\author{
Bree Richey ${ }^{\text {a }}$, Katelynn M. Mason ${ }^{\text {a }}$, Michael S. Meyers ${ }^{\text {a }}$, Sarah B. Luesse ${ }^{\text {a }}$ * \\ ${ }^{a}$ Department of Chemistry, Southern Illinois University Edwardsville, Edwardsville, Illinois, 62026, USA
}

\section{ARTICLE INFO}

ABSTRACT

\section{Article history:}

Received

Received in revised form

Accepted

Available online

\section{Keywords:}

Ugi-Smiles coupling;

Diels-Alder cycloaddition;

Oxatricycle;

Epoxyisoindoline;

multicomponent coupling reaction;
Use of allylamine and substituted 2-furaldehydes as components in Ugi-Smiles couplings of 2nitrophenol provide ready access to $N$-aryl epoxyisoindolines. These adducts form via a dual event involving the Ugi-Smiles multicomponent reaction and an intramolecular Diels-Alder cycloaddition with the furan ring.
The Ugi four-component reaction ${ }^{1}$ provided a foundation for the development of novel isocyanide-based multicomponent reactions (IMCRs) ${ }^{2}$ to efficiently access heterocyclic scaffolds. ${ }^{3}$ A particularly useful modification of these foundational IMCRs was reported as the Ugi-Smiles reaction by El Kaïm and coworkers, ${ }^{4,5}$ in which electron-deficient phenols serve as surrogates for the standard carboxylic acid components. The UgiSmiles reaction has been reported in one-pot cascade processes with Sonogashira couplings, ${ }^{6}$ acidic cyclizations, ${ }^{7}$ palladiumcatalyzed deallylations, ${ }^{8}$ and copper-triggered oxidative cycloadditions ${ }^{9}$ to prepare diverse heterocyclic libraries.

One notable limitation of the reported Ugi-Smiles reaction is the lack of reactivity observed for use of $\alpha, \beta$-unsaturated aldehydes or 2-furaldehyde as components. ${ }^{10,11}$ While the classical Ugi and Passerini reactions tolerate these aldehyde components, ${ }^{12}$ the analogous Ugi-Smiles reactions are generally unsuccessful. $^{13}$

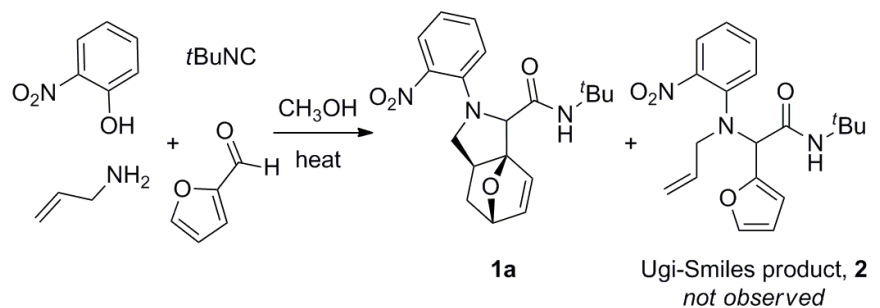

Scheme 1. $N$-Aryl epoxyisoindolines via Ugi-Smiles/IMDA
Table 1 Comparison of solvents for Ugi-Smiles/IMDA ${ }^{a}$<smiles>C=CCNC(=O)C1N(c2ccccc2[N+](=O)[O-])CC2CC3C=CC21O3</smiles>

\begin{tabular}{llcc}
\hline Entry & Solvent & Temperature & Yield $(\%)^{b}$ \\
\hline 1 & $\mathrm{CF}_{3} \mathrm{CH}_{2} \mathrm{OH}$ & $60^{\circ} \mathrm{C}$ & 21 \\
2 & $\mathrm{CH}_{3} \mathrm{OH}$ & $60^{\circ} \mathrm{C}$ & 52 \\
3 & $\mathrm{CH}_{3} \mathrm{OH}$ & $100{ }^{\circ} \mathrm{C}$, sealed tube & 40 \\
4 & $\mathrm{H}_{2} \mathrm{O}$ & $60^{\circ} \mathrm{C}$ & 53 \\
5 & $\mathrm{CH}_{3} \mathrm{CN}$ & $60^{\circ} \mathrm{C}$ & 26 \\
6 & Toluene & $60^{\circ} \mathrm{C}$ & 8 \\
7 & neat & $60^{\circ} \mathrm{C}$ & 50
\end{tabular}

${ }^{a}$ Standard reaction $(0.5 \mathrm{mmol}, 1.0 \mathrm{M})$ performed with 2.0 equiv tert-butyl isocyanide. ${ }^{b}$ Isolated yields represent the sum of the two diastereomers obtained after products were separated via column chromatography.

We were interested in exploring 2-furaldehyde and allylamine as the respective aldehyde and amine components in an UgiSmiles coupling, providing a system amenable for cascade with an intramolecular Diels-Alder reaction, to directly prepare conformationally-constrained oxatricycles. ${ }^{14}$ Successful IMDA reactions with a furan diene (IMDAF) have been reported 
Table 2 Ugi-Smiles/IMDA with Substituted 2-Furaldehydes ${ }^{a}$<smiles>[R]c1cc(C(=O)[CH-][CH]C)oc1[R]</smiles>

(1)

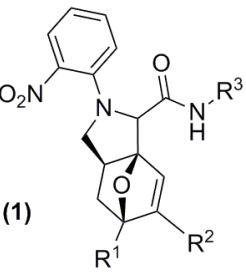

\begin{tabular}{|c|c|c|c|c|c|c|}
\hline Entry & $\mathrm{R}^{1}$ & $\mathrm{R}^{2}$ & $\mathrm{R}^{3}$ & Time / Temp & Product & Yield $(\%)^{b}$ \\
\hline 1 & $\mathrm{H}$ & $\mathrm{H}$ & tert-Butyl & $24 \mathrm{~h} / 60^{\circ} \mathrm{C}$ & $1 \mathbf{a}$ & 52 \\
\hline 2 & $\mathrm{Cl}$ & $\mathrm{H}$ & tert-Butyl & $24 \mathrm{~h} / 60^{\circ} \mathrm{C}$ & $1 b$ & 34 \\
\hline 3 & $\mathrm{Br}$ & $\mathrm{H}$ & tert-Butyl & $24 \mathrm{~h} / 60^{\circ} \mathrm{C}$ & 1c & 43 \\
\hline 4 & I & $\mathrm{H}$ & tert-Butyl & $24 \mathrm{~h} / 60^{\circ} \mathrm{C}$ & 1d & 48 \\
\hline 5 & $\mathrm{CH}_{3}$ & $\mathrm{H}$ & tert-Butyl & $42 \mathrm{~h} / 60^{\circ} \mathrm{C}$ & $1 \mathrm{e}$ & 49 \\
\hline 6 & $\mathrm{CH}_{3}$ & $\mathrm{CH}_{3}$ & tert-Butyl & $30 \mathrm{~h} / 50^{\circ} \mathrm{C}$ & 1f & 42 \\
\hline 7 & $\mathrm{H}$ & $\mathrm{Br}$ & tert-Butyl & $30 \mathrm{~h} / 50^{\circ} \mathrm{C}$ & $1 \mathrm{~g}$ & 56 \\
\hline 8 & $\mathrm{H}$ & $\mathrm{H}$ & Cyclohexyl & $24 \mathrm{~h} / 60^{\circ} \mathrm{C}$ & $1 \mathrm{~h}$ & 68 \\
\hline 9 & $\mathrm{Br}$ & $\mathrm{H}$ & Cyclohexyl & $30 \mathrm{~h} / 50^{\circ} \mathrm{C}$ & $\mathbf{1 i}$ & $60 / 42^{c}$ \\
\hline 10 & I & $\mathrm{H}$ & Cyclohexyl & $30 \mathrm{~h} / 50^{\circ} \mathrm{C}$ & $\mathbf{1 j}$ & $59 / 50^{c}$ \\
\hline 11 & $\mathrm{CH}_{3}$ & $\mathrm{H}$ & Cyclohexyl & $30 \mathrm{~h} / 50^{\circ} \mathrm{C}$ & $1 \mathrm{k}$ & $60 / 48^{c}$ \\
\hline 12 & $\mathrm{CH}_{3}$ & $\mathrm{CH}_{3}$ & Cyclohexyl & $30 \mathrm{~h} / 50^{\circ} \mathrm{C}$ & 11 & $51^{c}$ \\
\hline
\end{tabular}

${ }^{a}$ Standard reaction performed with 2.0 equiv isocyanide in methanol $(1.0 \mathrm{M}) .{ }^{b}$ Only exo-adduct observed. Both diastereomers at $\alpha$-amino amide carbon observed. Isolated yields represent the sum of the two diastereomers $(\sim 1: 1 \mathrm{dr})$ obtained after products were separated via column chromatography; see Supporting Information for details. ${ }^{c}$ Performed with 1.0 equiv isocyanide, $30 \mathrm{~h}, 50{ }^{\circ} \mathrm{C}$.

extensively for systems with tethered furanylamides, ${ }^{15}$ alkenyl furfurylamines, ${ }^{16}$ or in sequence with an Ugi or Passerini MCR, ${ }^{17}$ leading to formation of diverse oxabicyclo[2.2.1] systems. ${ }^{18}$

Herein, we report an efficient Ugi-Smiles coupling/intramolecular Diels-Alder cycloaddition (US/IMDA) with 2-furaldehyde, which provides direct access to $\mathrm{N}$-aryl epoxyisoindoline 1a through a simple, one-pot reaction (Scheme 1). Notably, no lone Ugi-Smiles adducts (2) were isolated for any reactions that used 2-furaldehyde. The remainder of recovered mass consisted of unreacted phenol and imine, formed in situ from 2-furaldehyde and allylamine. In the absence of a competent dienophile component, using aliphatic amines, no significant Ugi-Smiles coupled products were observed by ${ }^{1} \mathrm{H}$ NMR monitoring.

Methanol or toluene are the preferred solvents for Ugi-Smiles reactions, although water has also been used at elevated temperatures. ${ }^{19}$ Several solvents were screened for the dual UgiSmiles/IMDA process (Table 1) ${ }^{20}$ including toluene, acetonitrile, water, and trifluoroethanol. Yields decreased as aprotic solvents were examined. Water, methanol, and solvent-free conditions provided comparable yields. Lower product conversion was observed when heating in methanol at an elevated temperature $\left(100{ }^{\circ} \mathrm{C}\right)$ in a sealed Schlenk tube (entry 3$)$. Diastereomeric ratios for products 1a $(\mathbf{A}: \mathbf{B})$ were always close to 1:1. Relative amounts of the diastereomers and absence of Ugi-Smiles product (2) were supported by ${ }^{1} \mathrm{H}$ NMR spectra of the crude reaction mixtures and confirmed by isolated yields. Based on these solvent studies, methanol was used to examine the scope of the reaction with substituted 2-furaldehydes.

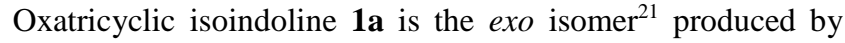
intramolecular Diels-Alder reaction of the furan and allyl moieties. Two diastereomeric exo adducts were readily separable by column chromatography. Relative stereochemical determination by ${ }^{1} \mathrm{H}$ NMR, NOESY correlations, and X-ray crystallographic analysis identified the less polar diastereomer (1a-A) having the amide moiety on the opposite side of the ring system from the oxygen bridge while the more polar diastereomer (1a-B) has the amide moiety on the same side as the oxabridge (Figure 1).
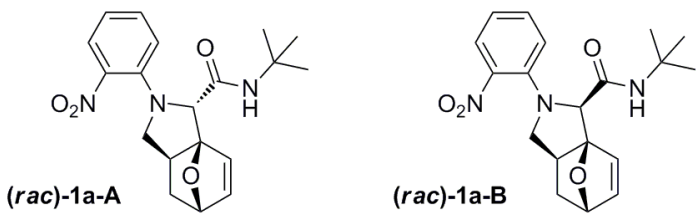

\section{Figure 1. Relative stereochemistry of $\mathbf{1 a - A}$ and $\mathbf{1 a - B}$}

We probed the scope of this reaction with several substituted 2-furaldehyde components (Table 2). Couplings with allylamine, 2-nitrophenol, and substituted 2-furaldehydes that included cyclohexyl isocyanide or tert-butyl isocyanide were successful, with two diastereomeric exo products isolated in moderate to good yields for each synthetic variation. 5-Halo-substituted 2furaldehydes (entries 2-4, 9 and 10) and alkyl 2-furaldehydes (entries 5-6, 11 and 12) were competent partners for this process. Use of 4-bromo-2-furaldehyde (entry 7) also provided the expected US/IMDA product. Notably, use of electron-rich 5methoxy-2-furaldehyde or electron-poor 5-nitro-2-furaldehyde as the aldehyde component provided no observed Ugi-Smiles or Ugi-Smiles/IMDA products. 
Due to volatility concerns for allylamine, several reactions were performed at slightly reduced temperatures $\left(50{ }^{\circ} \mathrm{C}\right)$. Equimolar amounts of the four components provide oxatricyclic isoindoline 1, although increased yields were observed with the use of excess isocyanide. For reactions involving cyclohexyl isocyanide as a component, this increase in yield was accompanied by the formation of 1-allyl-3-cyclohexylurea, from the side reaction of cyclohexyl isocyanide and allyl amine. While product yields were improved with excess cyclohexyl isocyanide compared to equimolar reactions, difficult purifications accompanied these attempts, as the urea byproduct was similar in polarity to the less polar diastereomer (1-A).

In conclusion, this work offers the first examples of successful four-component Ugi-Smiles derived couplings with conjugated, heterocyclic aldehydes. $N$-aryl epoxyisoindoline structures are efficiently assembled from simple starting materials with points of diversity on the furan ring, providing straightforward access to conformationally-restricted oxatricyclic building blocks. We are currently extending these studies to examine alternate compatible dienophile components for this process.

\section{Acknowledgments}

This research was supported by a Cottrell College Science Award (S. L.) from Research Corporation for Science Advancement. The authors acknowledge support from Southern Illinois University Edwardsville College of Arts and Sciences and the Graduate School. Thanks to Dr. Nigam Rath (UMSL) for solving the single crystal Xray structures supporting assignment of diastereomers 1-A and 1-B. S. L. thanks Prof. Jeffrey N. Johnston (VU) for helpful discussions during the preparation of this manuscript.

\section{Supplementary data}

Supplementary data (complete experimental procedures and product characterization data) associated with this article can be found, in the online version, at ...

\section{References and notes}

1. (a) Ugi, I.; Steinbrückner, C. Angew. Chem. 1960, 72, 267. (b) Ugi, I. Angew. Chem. Int. Ed. Engl. 1962, 8.

2. For reviews on isocyanide-based multicomponent reactions, see: (a) Dömling, A. Chem. Rev. 2006, 106, 17. (b) Dömling, A.; Ugi, I. Angew. Chem. Int. Ed. 2000, 39, 3168

3. Rotstein, B. H.; Zaretsky, S.; Rai, V.; Yudin, A. K. Chem. Rev. 2014, 114, 8323.

4. (a) El Kaïm, L.; Grimaud, L.; Oble, J. Angew. Chem. Int. Ed. 2005, 44, 7961. (b) El Kaïm, L.; Grimaud, L.; Pravin, P. J. Org. Lett. 2012, 14, 476 .

5. For reviews of Ugi-Smiles couplings, see: (a) El Kaïm, L.; Grimaud, L. Eur. J. Org. Chem. 2014, 35, 7749. (b) El Kaïm, L.; Grimaud, L. Mol. Divers. 2010, 14, 855. (b) El Kaïm, L.; Grimaud, L. Tetrahedron 2009, 65, 2153.

6. El Kaïm, L.; Grimaud, L.; Wagschal, S. J. Org. Chem. 2010, 75, 5343.

7. El Kaïm, L.; Grimaud, L.; Wagschal, S. J. Org. Chem. 2011, 76, 4728.

8. Coffinier, D.; El Kaïm, L.; Grimaud, L. Org. Lett. 2009, 11, 995.

9. Dos Santos, A.; El Kaïm, L.; Grimaud, L.; Ronsseray, C. Beilstein J. Org. Chem. 2011, 7, 1310 .

10. El Kaïm, L.; Gizolme, M.; Grimaud, L.; Oble, J. J. Org. Chem. 2007, 72, 4169 .

11. Chéron, N.; Ramozzi, R.; El Kaïm, L.; Grimaud, L.; FleuratLessard, P. J. Phys. Chem. A 2013, 117, 8035.

12. Ilyin, A.; Kysil, V.; Krasavin, M.; Kurashvili, I.; Ivachtchenko, A. V. J. Org. Chem. 2006, 71, 9544.

13. One report of a $\mathrm{Ti}(\mathrm{iOPr})_{4}$-catalyzed phenol U-4CR describes a successful Ugi-Smiles-like reaction with 2-furaldehyde, in the absence of an amine. Dai, W.-M.; Li, H. Tetrahedron 2007, 63, 12866

14. For reviews of the intramolecular Diels-Alder reaction, see: (a) Juhl, M.; Tanner, D. Chem. Soc. Rev. 2009, 38, 2983. (b) Takao, K. I.; Munakata, R.; Tadano, K.I. Chem. Rev. 2005, 105, 4779.

15. (a) Crawford, K. R.; Bur, S. K.; Straub, C. S.; Padwa, A. Org. Lett. 2003, 5, 3337. (b) Padwa, A.; Crawford, K. R.; Straub, C. S. J. Org. Chem. 2006, 71, 5432.

16. (a) Mance, A. D.; Šindler-Kulyk, M.; Jakopčić, K.; HergoldBrundić, A.; Nagl, A. J. Heterocyclic Chem. 1997, 34, 1315. (b) Mance, A. D.; Jakopčić, K.; Šindler-Kulyk, M. Synth. Commun. 1996, 26, 923. (c) Bilović, D.; Hahn, V. Croat. Chem. Acta 1967, 39, 189.

17. (a) Paulvannan, K. Tetrahedron Lett. 1999, 40, 1851. (b) Wright, D. L.; Robotham, C. V.; Aboud, K. Tetrahedron Lett. 2002, 43, 943.

18. (a) Kappe, C. O.; Murphree, S. S.; Padwa, A. Tetrahedron 1997, 53, 14179. (b) Keay, B. A.; Hunt, I. R. In Advances in Cycloaddition, Harmata, M., Ed; Elsevier, 1999; Vol. 6, pp 173 210. (c) Padwa, A.; Flick, A. C. In Advances in Heterocyclic Chemistry, Katritzky, A. R., Ed.; Academic Press, 2013; Vol. 110, pp 1-41.

19. El Kaïm, L.; Grimaud, L.; Purumandla, S. R. Tetrahedron Lett. 2010, 51, 4962 .

20. Typical procedure for Ugi-Smiles/IMDA coupling (Table 1, entry 2). To a solution of 2-nitrophenol $(69.5 \mathrm{mg}, 0.5 \mathrm{mmol}, 1$ equiv) in methanol $(0.50 \mathrm{~mL})$ was added 2 -furaldehyde $(41 \mu \mathrm{L}, 0.5 \mathrm{mmol}, 1$ equiv), allyl amine (38 $\mu \mathrm{L}, 0.5 \mathrm{mmol}, 1$ equiv), and tert-butyl isocyanide ( $114 \mu \mathrm{L}, 1.0 \mathrm{mmol}, 2$ equiv). The reaction mixture was warmed at $60{ }^{\circ} \mathrm{C}$ for $24 \mathrm{~h}$ under argon. Removal of volatiles gave the crude material, which was purified via flash column chromatography on silica gel (20\% ethyl acetate in hexanes) to afford 1a-A (42.5 mg, 24\%) and 1a-B (50.7 mg, 28\%).

1a-A: $\mathrm{R}_{f}=0.50(50 \%$ ethyl acetate/hexanes $) ;{ }^{1} \mathrm{H}$ NMR $(300 \mathrm{MHz}$, $\left.\mathrm{CDCl}_{3}\right) \delta 7.73(\mathrm{dd}, J=8.1,1.6 \mathrm{~Hz}, 1 \mathrm{H}), 7.49-7.44(\mathrm{~m}, 2 \mathrm{H}), 7.28$ $(\mathrm{d}, J=8.3 \mathrm{~Hz}, 1 \mathrm{H}), 7.07(\mathrm{dd}, J=7.9,7.9 \mathrm{~Hz}, 1 \mathrm{H}), 6.43(\mathrm{~d}, J=5.9$ $\mathrm{Hz}, 1 \mathrm{H}), 6.40(\mathrm{dd}, J=5.9,1.6 \mathrm{~Hz}, 1 \mathrm{H}), 5.06(\mathrm{dd}, J=4.4,1.5 \mathrm{~Hz}$, $1 \mathrm{H}), 4.55(\mathrm{~s}, 1 \mathrm{H}), 3.78(\mathrm{dd}, J=8.4,8.4 \mathrm{~Hz}, 1 \mathrm{H}), 2.74(\mathrm{dd}, J=9.6$, $9.6 \mathrm{~Hz}, 1 \mathrm{H}), 2.25-2.16(\mathrm{~m}, 1 \mathrm{H}), 1.78-1.71(\mathrm{~m}, 1 \mathrm{H}), 1.46(\mathrm{dd}, J=$ $11.6,7.6 \mathrm{~Hz}, 1 \mathrm{H}), 1.31(\mathrm{~s}, 9 \mathrm{H}) ;{ }^{13} \mathrm{C}$ NMR $\left(75 \mathrm{MHz}, \mathrm{CDCl}_{3}\right) \delta$ 168.6, 142.7, 142.0, 136.5, 134.1, 130.6, 125.9, 122.4, 121.8, 97.2, $80.1,65.9,58.1,51.3,42.1,30.9,28.7$; HR-FAB MS $[\mathrm{M}+\mathrm{Na}]^{+}$ calcd for $\mathrm{C}_{19} \mathrm{H}_{23} \mathrm{~N}_{3} \mathrm{NaO}_{4} 380.1586$; found 380.1594 .

1a-B: $\mathrm{R}_{f}=0.27\left(50 \%\right.$ ethyl acetate/hexanes); ${ }^{1} \mathrm{H}$ NMR $(300 \mathrm{MHz}$, $\left.\mathrm{CDCl}_{3}\right) \delta 7.77(\mathrm{~d}, J=8.2 \mathrm{~Hz}, 1 \mathrm{H}), 7.41(\mathrm{dd}, J=8.6,8.6 \mathrm{~Hz}, 1 \mathrm{H})$, $7.05(\mathrm{~d}, J=8.3 \mathrm{~Hz}, 1 \mathrm{H}), 7.00(\mathrm{dd}, J=7.7,7.7 \mathrm{~Hz}, 1 \mathrm{H}), 6.56-6.43$ $(\mathrm{m}, 3 \mathrm{H}), 5.15(\mathrm{dd}, J=4.5,1.6 \mathrm{~Hz}, 1 \mathrm{H}), 4.80(\mathrm{~s}, 1 \mathrm{H}), 3.45(\mathrm{dd}, J=$ 9.8, $9.8 \mathrm{~Hz}, 1 \mathrm{H}), 3.01(\mathrm{dd}, J=9.1,9.1 \mathrm{~Hz}, 1 \mathrm{H}), 2.22-2.12(\mathrm{~m}, 1 \mathrm{H})$, $1.89-1.82(\mathrm{~m}, 1 \mathrm{H}), 1.46-1.39(\mathrm{~m}, 1 \mathrm{H}), 1.19(\mathrm{~s}, 9 \mathrm{H}) ;{ }^{13} \mathrm{C} \mathrm{NMR}(75$ $\left.\mathrm{MHz}, \mathrm{CDCl}_{3}\right) \delta 166.5,141.7,139.0,137.9,134.0,133.4,126.4$, $118.8,116.4,95.6,80.8,64.4,58.2,51.3,42.7,31.4,28.5$; IR $\left(\mathrm{KBr}\left[\mathrm{cm}^{-1}\right]\right): 3386(\mathrm{~m})[\mathrm{N}-\mathrm{H}], 3054(\mathrm{~m})[\mathrm{C}-\mathrm{H}], 1678(\mathrm{~s})[\mathrm{C}=\mathrm{O}]$, 1265 (s) [C-O], 739 (s) [C-N]; HR-FAB MS [M+H] $]^{+}$calcd for $\mathrm{C}_{19} \mathrm{H}_{24} \mathrm{~N}_{3} \mathrm{O}_{4}$ 358.1767; found 358.1760 .

21. This preference for the exo isomer is consistent with previous studies of IMDAF reactions: (a) Read, R. L.; Krapp, A.; Miranda, P. O.; Gundersen, L.-L. Tetrahedron 2012, 68, 1869. (b) Varlamov, A. V.; Boltukhina, E. V.; Zubkov, F. I.; Nikitina, E. V.; Turchin, K. F. J. Heterocylic Chem. 2006, 43, 1479. (c) Ghelfi, F.; Parsons, A. F.; Tommasini, D.; Mucci, A. Eur. J. Org. Chem. 2001, 1845. (d) Padwa, A.; Brodney, M. A.; Satake, K.; Straub, C. S. J. Org. Chem. 1999, 64, 4617. 